\title{
Elisabetta Baldisserotto, Invidia e Gratitudine. La malattia dello sguardo: il caso della cugina Betta
}

\section{Marco Stupazzzoni}

\section{(2) OpenEdition}

1 Journals

\section{Edizione digitale}

URL: http://journals.openedition.org/studifrancesi/3785

DOI: $10.4000 /$ studifrancesi.3785

ISSN: 2421-5856

\section{Editore}

Rosenberg \& Sellier

\section{Edizione cartacea}

Data di pubblicazione: 1 décembre 2012

Paginazione: 588

ISSN: 0039-2944

\section{Notizia bibliografica digitale}

Marco Stupazzzoni, «Elisabetta Baldisserotto, Invidia e Gratitudine. La malattia dello sguardo: il caso della cugina Betta», Studi Francesi [Online], 168 (LVI | III) | 2012, online dal 30 novembre 2015, consultato il 06 mars 2021. URL: http://journals.openedition.org/studifrancesi/3785 ; DOI: https://doi.org/10.4000/

studifrancesi.3785

Questo documento è stato generato automaticamente il 6 mars 2021.

\section{(c)}

Studi Francesi è distribuita con Licenza Creative Commons Attribuzione - Non commerciale - Non opere derivate 4.0 Internazionale. 


\section{Elisabetta Baldisserotto, Invidia e Gratitudine. La malattia dello sguardo: il caso della cugina Betta}

Marco Stupazzzoni

\section{NOTIZIA}

ELISABETTA BALDISSEROTTO, Invidia e Gratitudine. La malattia dello sguardo: il caso della cugina Betta, in Leggere i sentimenti. Un percorso psicologico e letterario con un saggio di Augusto ROMANo, Bergamo, Moretti \& Vitali, «Il Tridente. Saggi», 2011, pp. 61-69.

1 L'A. considera il personaggio di Lisabetta Fischer, la protagonista de La Cousine Bette di Balzac, come un caso esemplare di personalità eccessivamente invidiosa, «strutturatasi su un trattamento ingiustamente ricevuto durante l'infanzia» (p. 63). Le ferite ricevute nel passato deformano, dunque, in Betta, la percezione del presente: in lei, scrive Balzac, l'invidia, vera e propria malattia dello sguardo impressa nei suoi profondi e torbidi occhi neri, «rimase nascosta nel fondo del suo cuore, come un germe di peste pronto a ridestarsi e a devastare un'intera città se si apre il fatale sacco in cui è chiuso». Ma l'invidia, alla fine, uccide l'individuo (in questo caso Betta) consumato per l'intera sua vita da una passione divorante: «La soggettività si esaurisce in essa, essendo incapace di esplicarsi in altri modi, sentendosi tuttavia sempre a rischio di annientamento» (p. 69). 